\title{
Efektivitas Pemberian Papain Getah Pepaya Terhadap Kadar Faktor Pertumbuhan Transforming Growth Factor -B (Tgf-B) pada Proses Penyembuhan Luka Bakar Tikus Percobaan
}

\author{
Gusti Revilla
}

\begin{abstract}
Abstrak
Pengobatan untuk luka bakar dengan menggunakan bahan alam sudah dilakukan, diantaranya madu lebah, lidah buaya dan papain. Papain merupakan enzim yang ditemukan pada getah papaya. Enzim ini mempunyai aktivitas katalitik yang mampu mengurangi jaringan parut akibat luka bakar. Tujuan penelitian ini adalah menentukan efektifitas papain getah papaya terhadap kadar faktor pertumbuhan Transforming growth factor - $\beta$ (TGF- $\beta$ ) pada Proses penyembuhan luka bakar tikus. Penelitian bersifat eksperimental dengan menggunakan 15 tikus sebagai obyek penelitian dan dibagi atas 3 kelompok yaitu kelompok kontrol, kelompok diberi papain dan kelompok pembanding diberi silver sulfadiazin. Tikus dibuat luka bakar partial dengan memanaskan logam pada air mendidih dan ditempelkan pada bagian dorsal tikus selama 20 detik. Tikus yang menderita luka bakar diberi perlakuan sesuai kelompok dan pada hari ke 5 diambil darah lewat mata untuk mendapatkan serum, selanjutnya dilakukan pengukuran kadar TGF- $\beta$ dengan metode Elisa. Hasil penelitian menunjukkan bahwa kadar rerata TGF- $\beta$ pada kelompok kontrol $317.72 \mathrm{pg} / \mathrm{ml}$, kelompok diberi papain $186.24 \mathrm{pg} / \mathrm{ml}$ dan kelompok pembanding $192.11 \mathrm{pg} / \mathrm{ml}$. Ini menunjukkan bahwa enzim papain mampu menurunkan kadar TGF- $\beta$ yang bersifat sebagai proinflamasi sehingga papain mungkin mampu mempercepat fase inflamasi dan juga mampu mempercepat proses penyembuhan lukaBahasa Indonesia
\end{abstract}

Kata kunci: papain, luka bakar, TGF- $\beta$

\section{Abstract}

Natural ingredients such as honey bees, aloe vera, and papain have been used in burns as topical treatments. Papain is an enzyme found in papaya latex. This enzyme has catalytic activity could be responsible for producing less scarring of the burn wound. The objective of this study was to determine the ability of papain papaya on levels of the growth factor Transforming growth factor-b 1 (TGF- $\beta 1$ ) in the healing process of rat burns. An experimental study had been carried out on 15 rats which were divided into three groups: control group, papain group and silver sulfadiazine group as a comparison group. A partial thickness burns was made by placing a hot boiled metal for 20 seconds on their shaved dorsum which has been anesthetized before with $2 \%$ lidocaine. At day 5 , levels of TGF- $\beta 1$ serum obtained from rat's eye was measured by ELISA. The results showed that the average TGF- $\beta$ level in the control group $317.72 \mathrm{pg} / \mathrm{ml}$ of the group was given papain $186.24 \mathrm{pg} / \mathrm{ml}$ and the comparison group $192.11 \mathrm{pg} / \mathrm{ml}$. This shows that the papain enzyme is able to reduce TGF- $\beta 1$ levels which are proinflammatory so that papain may be able to accelerate the inflammatory phase and also be able to accelerate the process of wound healing.

Keywords: papain burn TGF- $\beta 1$

Affiliasi penulis: Bagian Anatomi Fakultas Kedokteran Universtas Andalas Padang

Korespondensi: Gusti Revilla, Email: gustirevilla@med.unand.ac.id. Telp: 081363269604

\section{PENDAHULUAN}

Luka bakar merupakan salah satu masalah serius bagi masyarakat di dunia karena luka bakar akan menimbulkan kerusakan pada fisik dan bahkan ada yang menimbulkan kematian. Kerusakan pada 
fisik ini akan menyebabkan kecacatan dan akan mempengaruhi psikologis penderita ${ }^{1}$.

Di Indonesia belum ada data tertulis mengenai jumlah penderita dan jumlah angka kematian yang ditimbulkan akibat luka bakar. Berdasarkan data di RSUP M. Jamil Padang pada tahun 2015 diketahui bahwa kasus luka bakar mencapai 106 orang dengan penyebabnya berasal dari kompor dan alat elektrik dan tahun 2016 data ditemukan turun menjadi 86 kasus luka bakar dengan kasus paling banyak disebabkan dari sengatan listrik. ${ }^{2}$

Luka bakar merupakan suatu kerusakan yang kompleks yang terjadi pada jaringan baik secara lokal maupun sistemik. Luka bakar dapat disebabkan oleh suhu panas (thermal), kimia, elektrik, dan radiasi dan kerusakan yang terjadi tergantung pada letak, kedalaman dan luas dari luka bakar. Luka bakar yang luas dan dalam akan menimbulkan kerusakan berbagai organ diantaranya kulit dan saluran nafas serta menimbulkan komplikasi yaitu infeksi dan shock. Akibat dari luka bakar akan mempengaruhi morbiditas dan derajat cacat yang relatif tinggi dibandingkan dengan cidera luka lainnya dan membutuhkan biaya tinggi sehingga penderita luka bakar membutuhkan perawatan yang intensif di unit khusus., Pengurangan risiko yang ditimbulkan oleh luka bakar yang cukup kompleks maka diperlukan penanganan yang tepat dan baik, sehingga tidak mempengaruhi penyembuhan luka. ${ }^{1}$

Keadaan ini membutuhkan penanganan dan pengobatan yang tepat. Pengobatan untuk luka bakar yang telah digunakan baik bersumber dari alam maupun dengan menggunakan hasil teknologi yang baru yaitu dengan faktor pertumbuhan dan sel stem. Dari bahan alam telah dilakukan beberapa tanaman yang secara empiris diketahui mempunyai efek untuk penyembuhan luka. ${ }^{5}$ Penelitian yang telah dilakukan dari bahan alam yaitu propolis yang dibandingkan dengan SSD $1 \%$ terhadap penyembuhan luka bakar ternyata SSD $1 \%$ memerlukan waktu yang lebih lama jika dibandingkan dengan propolis. ${ }^{6}$ begitu juga dengan menggunakan madu, pemberian madu lebah lebih cepat menyembuhkan luka bakar dibandingkan dengan SSD $1 \%{ }^{7}$. Bahan alam lain yang secara empiris juga diketahui mempunyai efek terhadap penyembuhan luka adalah papain yang ada dalam getah pepaya.

Salah satu senyawa dari tanaman yang berpengaruh adalah papain yang ada dalam getah pepaya. Enzim papain termasuk jenis enzim sistein proteinase dan bersifat sebagai enzim proteolitik. Penelitian peran papain dalam penyembuhan luka sudah banyak dilakukan namun penelitian tersebut difokuskan pada pemeriksaan secara histologis yaitu melihat jumlah keropeng mencair yang dihubungkan dengan penurunan jumlah jaringan nekrotik ${ }^{8}$. Pada penelitian terhadap enzim protease diantaranya papain (dari pepaya) dan bromealin (dari buah nenas) diketahui bahwa ke 2 enzim ini dapat meningkatkan konsentrasi pelepasan dari interleukin-6 (IL-6), diketahui bahwa IL-6 berperan dalam inflamasi ${ }^{9}$. Pada penelitian lain ditemukan bahwa papain dapat meningkatkan penebalan epidermis, baik jumlah maupun kedalaman jalinan pembuluh darah serta meningkatkan jumlah kolagen dilapisan dermis dibandingkan dengan pemberian salep luka dengan bahan dasar urea. Mekanisme yang mungkin untuk penebalan epidermis dan peningkatan pembuluh darah diantaranya disebabkan oleh pelepasan faktor pertumbuhan, sitokin, kemokin dan ekspresi dari molekul adhesi ${ }^{10}$, namun mekanisme yang pasti dalam peningkatan jumlah pembuluh darah dan penghancuran jaringan nekrotik ini secara molekular belum dilakukan penelitiannya. Untuk itu dilakukan penelitian lanjutan efek papain getah pepaya terhadap kadar faktor pertumbuhan diantaranya yaitu Transforming growth factor $-\beta$ (TGF- $\beta$ ) yang berpengaruh pada proses penyembuhan luka.

\section{METODE}

\section{Papain}

Enzim papain didapatkan dari pabrik Nacalai Tesque Kyoto Japan berupa cairan yang berisi $25 \mathrm{mg}$ dalam $1.2 \mathrm{ml}$.

\section{Hewan Percobaan}

Sebagai obyek penelitian digunakan tikus putih (Rattus novergicus) galur Wistar dengan berat 180 200 gr yang diperoleh dari Labor Farmakologi Fakultas Farmasi Unand. Hewan dipelihara untuk aklitimasi selama 1 minggu dilaboratorium Anatomi FK Unand. 
Protokol penelitian sudah lolos kajian etik dari komisi etika penelitian Kedokteran Universitas Andalas Padang.

\section{Cara Pelaksanaan Penelitian}

Tikus dibagi atas 3 kelompok yaitu kontrol, perlakuan dan kelompok pembanding. Kelompok kontrol diberi vaselin sedangkan kelompok perlakukan diberi papain dosis $0.5 \mathrm{mg} / \mathrm{kg}$ BB dan kelompok pembanding yaitu silver sulfadiazin (SSD). Masingmasing kelompok tikus dibuat luka bakar dengan cara memanaskan plat dengan suhu $60^{\circ} \mathrm{C}$ ditempelkan bagian dorsal (punggung) tikus selama 20 detik, tetapi tikus sebelumnya dianestesi secara injeksi intramuscular dengan lidocain $2 \%$. Tikus menderita luka bakar partial. Tikus yang luka akan diberi perlakuan sesuai dengan kelompoknya. Pada hari 5 di ambil darah untuk melihat kadar faktor pertumbuhan. Faktor pertumbuhan diamati dengan menggunakan metode Elisa keluaran R\&D system.

Pengukuran kadar faktor pertumbuhan TGF-, digunakan metode Elisa. Elisa merupakan teknik deteksi yang berdasarkan reaksi antigen antibodi. Antibodi diikat dengan enzim spesifik sebagai penanda. Bila ada reaksi positif, enzim akan menghidrolisis substrat sehingga terjadi perubahan warna yang dapat dibaca secara visual dengan menggunakan spektrofotometer. Jenis kit Elisa yang telah digunakan yaitu kit Elisa microplate.

\section{Analisa Data}

Analisis perbedaan pembentukan jaringan granulasi digunakan analisis Anova, perbedaan dinyatakan bermakna jika $p \leq 0.05$

\section{Etika Penelitian}

Pada penelitian tikus yang akan diperlakukan luka bakar terlebih dahulu dianestesi dengan menggunakan lidokain dan ditambah dengan analgesik decamidon. Penelitian ini sudah dilakukan etikal kliren sehingga disetujui untuk dilaksanakan. Tetapi jenis anestesi yang digunakan tidak sesuai dengan profosal penelitian karena sampai dilakukan penelitian anestesi tersebut tidak ditemukan dipasaran. Jenis analgesik yang digunakan adalah decamidon yang disarankan dari apoteker.
HASIL

Hasil penelitian terhadap kadar TGF- $\beta 1$ pada serum 30 ekor tikus yang mengalami luka bakar partial dari 3 kelompok dapat dilihat pada tabel 6.1 dibawah ini.

Tabel 1. Kadar TGF- $\beta 1$ (pg/ml) serum tikus yang mengalami luka bakar partial setelah diberi papain, vaselin dan SSD

\begin{tabular}{cccc}
\hline No & Kontrol & $\begin{array}{c}\text { Kelompok } \\
\text { Perlakuan }\end{array}$ & Pembanding \\
\hline 1 & 270.62 & 143.07 & 181.46 \\
2 & 203.75 & 207.46 & 266.90 \\
3 & 361.01 & 151.55 & 159.17 \\
4 & 394.44 & 199.75 & 203.75 \\
5 & 358.53 & 229.38 & 149.27 \\
\hline rerata & 317.72 & 186.24 & 192.11 \\
\hline
\end{tabular}

Pada tabel di atas terlihat kadar dari TGF- $\beta 1$ bervariasi, ini mungkin menunjukkan bahwa setiap individu hewan tersebut mempunyai respon imunitas yang berbeda. Pada tabel diatas juga terlihat bahwa tikus yang diberi papain kadar rerata TGF- $\beta 1$ sedikit rendah dibandingkan dengan SSD secara statistik tidak menunjukkan perbedaan yang bermakna, tetapi jika kadar TGF- $\beta 1$ kelompok perlakuan dan pembanding tersebut dibandingkan dengan kelompok kontrol secara statistik terdapat perbedaan yang bermakna pada tingkat $p=0.05$.

\section{PEMBAHASAN}

Papain telah digunakan untuk penelitian luka bakar pada hewan percobaan dan secara histologis menunjukkan bahwa papain dapat meningkatkan penebalan epidermis, jalinan pembuluh darah serta meningkatkan jumlah kolagen dilapisan dermis dibandingkan dengan pemberian salep luka dengan bahan dasar urea ${ }^{10}$. Mekanisme kondisi tersebut mungkin diantaranya disebabkan oleh pelepasan faktor pertumbuhan, sitokin, kemokin dan ekspresi dari molekul adhesi.

Berdasarkan hasil penelitian terhadap kadar TGF- $\beta 1$ pada tikus luka bakar partial antara tikus kontrol yang hanya diberi vaselin dengan kelompok perlakuan diberi papain dan pembanding diberi SSD secara statistik terlihat adanya perbedaan yang 
bermakna pada tingkat $\mathrm{p}=0.05$, ini menunjukkan bahwa papain dan SSD memberikan pengaruh yang cukup baik untuk penyembuhan luka bakar pada derajat partial, namun antara kelompok yang diberi papain dengan pembanding secara angka kadar TGF$\beta 1$ terlihat ada perbedaan tetapi secara statistik tidak menunjukkan perbedaan yang bermakna. Penurunan kadar TGF- $\beta 1$ pada penelitian ini menunjukkan bahwa papain mampu mempercepat fase inflamasi mungkin mengurangi infiltrasi dari monosit sehingga mempercepat fase-fase lain dari penyembuhan luka. TGF- $\beta$ diketahui berperan penting dalam inflamasi, angiogenesis dengan cara meningkatkan regulasi dari VEGF, reepitelisasi dengan meningkatkan proliferasi dari keratinosit dan regenerasi jaringan ikat. ${ }^{11,12}$ TGF- $\beta$ 1 pada fase remodelling penyembuhan luka berperan dalam produksi kolagen. ${ }^{13}$

Pada kelompok yang diberi papain pada luka bakar derajat partial terlihat bahwa, papain mampu mengangkat bekas luka atau keropeng pada tikus luka bakar tersebut. Ini menunjukkan bahwa papain mungkin lebih cepat memperbaiki penyembuhan luka. Kondisi ini juga menyokong penelitian yang dilakukan oleh Shuid et al (2005) yang menemukan bahwa getah pepaya mampu membersihkan luka, mengurangi jaringan bekas luka dan mengurangi rasa nyeri akibat luka bakar pada tikus percobaan. ${ }^{14}$ Mekanisme membersihkan jaringan luka mungkin disebabkan oleh kemampuan papain untuk meningkatkan kemampuan sel-sel inflamasi untuk memfagositosis sel rusak disekitar luka, karena diketahui TGF- $\beta$ 1. berfungsi untuk merubah monosit menjadi makrofag. ${ }^{15}$

Peran papain ini terhadap produksi dari faktor pertumbuhan tentu akan dapat membantu proses penyembuhan luka, namun tentu perlu penelitian lebih lanjut karena banyak faktor pertumbuhan dan sitokin yang terlibat dalam proses penyembuhan luka. Untuk itu perlu penelitian lebih lanjut tentang pengukuran kadar faktor pertumbuhan dan sitokin lainnya untuk memperkuat peran papain selama penyembuhan luka.

\section{SIMPULAN}

Pemberian papain pada tikus luka bakar lebih efektif dibandingkan dengan SSD dilihat dari kadar rerata TGF- $\beta 1$ pada penyembuhan luka. Tidak terdapat perbedaan yang bermakna kadar rerata TGF$\beta 1$ pada tikus luka bakar dengan penggunaan papain dengan SSD pada penyembuhan luka.

\section{SARAN}

Perlu penelitian lebih lanjut peran papain terhadap kadar faktor pertumbuhan dan sitokin yang berperan dalam proses penyembuhan luka

\section{DAFTAR PUSTAKA}

1. Evers LH, Bhavsar D, Mailander P. The Biology of burn injury. Experimental Dermatology. 2010;19: 777-83.

2. RSUP Dr M Djamil. Data laporan pasien yang dirawat di RSUP Dr. M. Djamil Padang tahun 20015 - 2016. Padang: RSUP Dr M Djamil; 2017.

3. Syamsuhidayat R. Buku ajar ilmu bedah. Edisi Revisi. Jakarta: Penerbit Buku Kedokteran EGC; 1997.

4. Vern AK, Latense BA. Specimen collection and analysis burn wound. Methods in molecular medicine wound healing. Vol.78. Edited by Luisa D and Aime LB. Totowa NJ: Human Press Inc; 2001.

5. Scott EM, Leaper DJ,Clark M. Effects of warming therapy on pressure ulcers - a randomised trial. AORN Journal 2001;73:921-38.

6. Khorasgani EM. A comparison of healing effect of propolis and silver sulfadiazine of full thickness skin wound in rats. Pakistan Veterinary journal. 2010;30(2):72-4.

7. Baghel PS, Shukla S, Mathur RK, Randa R. A comparative study to evaluate the effect of honey dressing and silver sulfadiazine dressing on wound healing in burn patients. Indian J Plastic surgery. 2009;42(2):176-81.

8. Schultz GS, Sibbald RG, Falanga V, Ayello, EA, Dowsett $C$. Wound bed preparation: a systemic approach to wound management. Wound Repair and Regeneration. 2003;11:1-28.

9. Rose BC, Herder H. Loffler' G. Meierchoff N.C, Schloot M. Walz S. Martin. Dose-dependent induction of IL- 6 by plant derived proteases in vitro. British society for immunology. Clinical and Experimental immunology, 2005;143:85-92.

10. Tolgenhoff D, Kan L, Sarah R, Valerie V, Kristine $\mathrm{V}$, et al. Influence of papain urea copper 
chlorophylin on wound matrix remodelling. Wound Repair and Regeneration. 2007;15:727-35.

11. Werner S, Grose R. Regulation of wound healing by growth factors and cytokines. Zurich, Switerland. American Physiological Society. 2003; 83:835-70.

12. Riedel K, Riedel F, Goessler UR, Germann G, Sauerbier M. Tgf-beta antisense therapy increases angiogenic potential in human keratinocytes in vitro. Arch Med Res. 2007;38:45-51.

13. White LA, Mitchell TI, Brinckerhoff CE. Transforming growth factor beta inhibitory element in the rabbit matrix metalloproteinase-1 (collagenase-1) gene functions as a repressor of constitutive transcription. Biochim Biophys Acta. 2000;1490:259-68.

14. Shuid AN, Mohamad SA, Ahmad AY. The effects of Carica papaya linn latex on the healing of burn wound in rats. Jurnal Sains Kesihatan Malaysia. 2005;3(2):39-47.

15. Barrientos S, Olivera S, Michael SG, Harold B, Marjana TM. Growth factors and cytokines in wound healing. Perspective article. J Wound repair and Regenerate. 2008;16:585-601. 